\title{
Detection of Group 2a Coronaviruses with Emphasis on Bovine and Wild Ruminant Strains
}

\author{
Virus Isolation and Detection of Antibody, Antigen, \\ and Nucleic Acid
}

Mustafa Hasoksuz, Anastasia Vlasova, and Linda J. Saif

\begin{abstract}
Group 2a of the Coronaviridae family contains human and animal pathogens that include mouse hepatitis virus, rat coronavirus, human respiratory coronaviruses OC43 and the recently identified HKU1 strain, a newly recognized canine respiratory coronavirus, porcine hemagglutinating encephalomyelitis virus, equine coronavirus, bovine coronavirus $(\mathrm{BCoV})$, and wild-ruminant coronaviruses. The presence of a hemagglutinin-esterase (HE) surface glycoprotein in addition to the viral spike protein is a distinguishing characteristic of most group 2a coronaviruses. $\mathrm{BCoV}$ is ubiquitous in cattle worldwide and is an economically significant cause of calf diarrhea, winter dysentery of adult cattle, and respiratory disease in calves and feedlot cattle. We have developed and optimized laboratory diagnostic techniques, including virus isolation in HRT-18 cell cultures, antibody and antigen ELISA, and RT-PCR, for rapid, sensitive, and reliable diagnosis of $\mathrm{BCoV}$ and related wild ruminant coronaviruses.
\end{abstract}

Key words: coronavirus; group 2a; bovine coronavirus (BCoV); wild-ruminant coronavirus; diagnostic tests; antibody detection; antigen detection; RT-PCR; polymerase chain reaction

\section{Introduction}

Coronaviruses cause a broad spectrum of diseases in domestic and wild animals, poultry, and rodents, ranging from mild to severe enteric, respiratory, and systemic disease, as well as the common cold or pneumonia in humans (1-3).

From: Methods in Molecular Biology, vol. 454: SARS- and Other Coronaviruses, Edited by: D. Cavanagh, DOI: 10.1007/978-1-59745-181-9_5, C Humana Press, New York, NY 
Recently SARS-CoV emerged, likely from a wildlife reservoir, as a new $\mathrm{CoV}$ (group 2b) causing severe respiratory disease in humans (4-10). Bats are a suspect reservoir for SARS-like CoVs with civet cats possibly playing a role as an intermediate host $(\mathbf{6}, \mathbf{8}-\mathbf{1 3})$.

The widespread prevalence of infections caused by group 2 coronaviruses, their extensive host range, the various disease manifestations, a high frequency of genomic recombination events, and the potential for interspecies transmission (BCoV, SARS-CoV) are characteristics that require continuous monitoring and improvement of diagnostic tests for these CoVs $(8,9)$. A summary of infections and standardized diagnostic tests available for group $2 \mathrm{a} \mathrm{CoVs}$ is shown in Table 1.

Our laboratory has focused extensively on the study of bovine coronavirus $(\mathrm{BCoV})$ and bovine-like $\mathrm{CoVs}$ for many years. Bovine coronavirus causes acute diarrhea in neonatal calves and winter dysentery in adult cattle causing large economic losses owing to diarrheal morbidity and mortality costs and decreased milk production $(2,27-31)$. The enteropathogenic coronaviruses were initially identified and isolated from neonatal calves with severe diarrhea (31). Subsequently, coronaviruses were revealed to be a cause of winter dysentery in adult cattle $(\mathbf{2 , 3 2 - 3 5 )}$ as well as respiratory disease (shipping fever pneumonia) $(29,36-40)$, and antigenic, biologic, and genetic variation among these strains was demonstrated $(\mathbf{2 8 , 3 7 , 4 1 - 4 3 )}$. Repeated upper respiratory BCoV infections occur frequently in calves, and subclinically infected animals may be reservoirs for $\mathrm{BCoV}(28,30)$.

Recently, bovine-like CoVs were recognized as important enteric pathogens in captive wild ruminants from the United States, including Sambar deer (Cervus unicolor), white-tailed deer (Odocoileus virginianus), waterbuck (Kobus ellipsiprymnus) (44), elk (Cervus elephus) (45), and giraffe (Giraffa camelopardalis) $(45 a)$. Coronaviruses isolated from these species were antigenically indistinguishable from $\mathrm{BCoV}(44)$. Furthermore, some wild ruminants such as caribou (Rangifer tarandus), sitatunga (Tragelaphus spekei), musk oxen (Ovibus moschatus), white-tailed deer (Odocoileus virginianus), and mule deer (Odocoileus hemionus) were shown to have antibodies to BCoV (44-47).

Detailed methods for cell culture propagation of the enteric BCoVs were described by Saif et al. in 1988 (48). General procedures for the isolation of winter dysentery (49) and respiratory strains of BCoV in HRT-18 cell cultures (using cloned HRT-18 cells from the L. J. Saif laboratory) (37), antibody and antigen ELISA, and RT-PCR have been optimized and standardized in our laboratory $(2,28,50,51)$ and are described in detail in the following sections. For the antigen (Ag) ELISA tests, monoclonal antibodies (MAb) were produced and characterized by our laboratory and standardized for routine use in ELISA, immunoblotting, and immunohistochemistry $(41,50-52)$. 


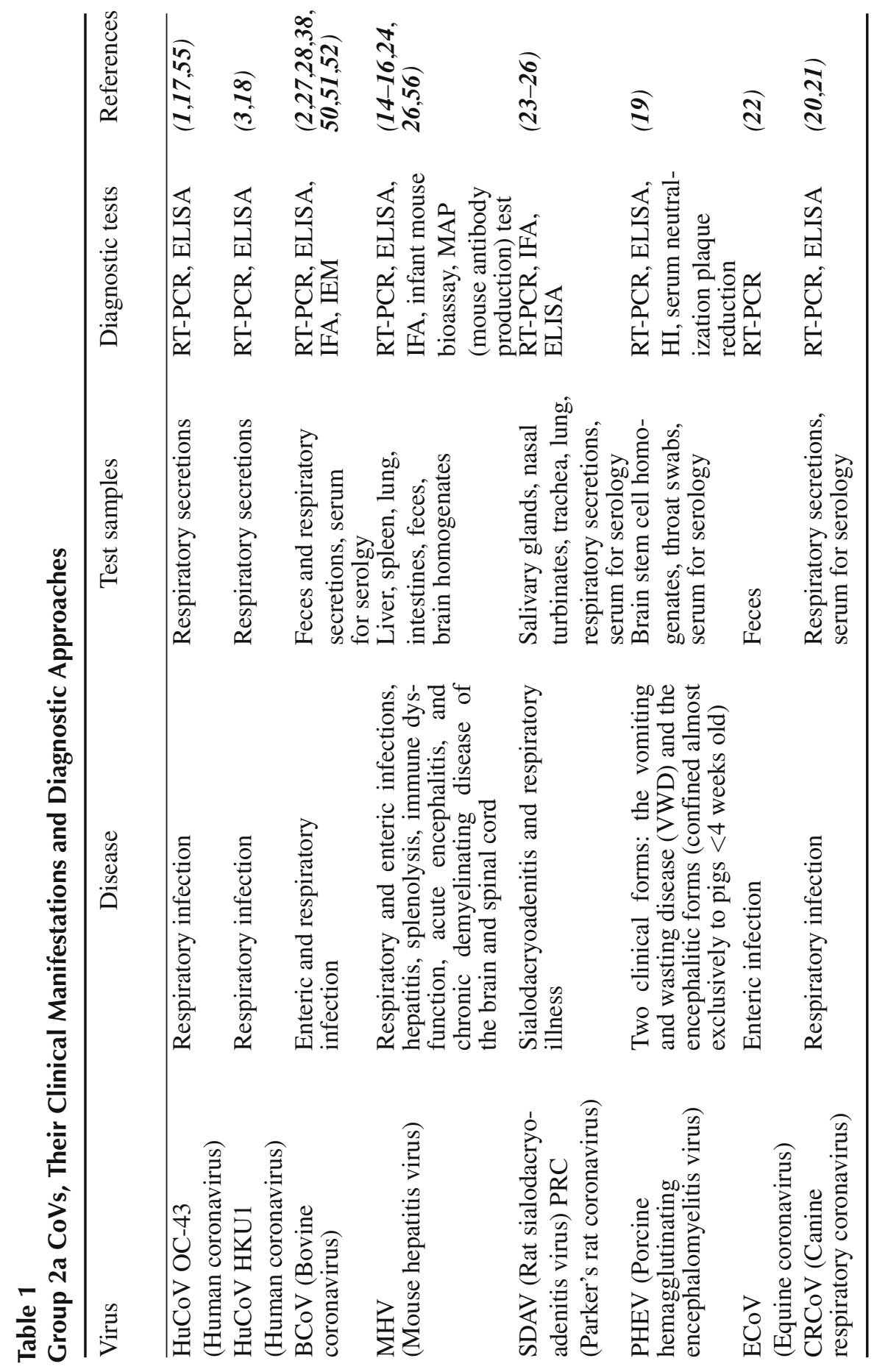




\section{Materials}

\subsection{Virus Isolation and Plaque Induction}

1. Advanced Minimal Eagle's Medium (Advanced MEM) (Gibco, Invitrogen Corporation, Grand Island, NY, USA)

2. Trypsin-EDTA $1 X$ (ethylendiamine tetraacetic acid) (1 mM) (Gibco).

3. Pancreatin solution (Sigma-Aldrich, St. Lois, MO, USA).

4. Fetal bovine serum, FBS (HyClone, Lawrenceville, GA, USA) (see Note 1).

5. L-Glutamine $(200 \mathrm{mM})$.

6. Antibiotic-antimycotic 100X liq. solution (Gibco).

7. Neutral red.

8. DEAE-Dextran (diethylaminoethyl-Dextran) (Sigma-Aldrich).

9. Diluent \#5 (Dil. \#5): Minimal essential medium, MEM (Gibco) supplemented with $1 \%$ of antibiotic-antimycotic solution (Gibco) and $1 \% \mathrm{NaHCO}_{3}$; final $\mathrm{pH}$ should be 7.2.

\subsection{Antigen-Capture ELISA for Detection of Viral Antigens}

1. Coating buffer-0.1 M carbonate bicarbonate buffer: $1.59 \mathrm{~g} \mathrm{Na}_{2} \mathrm{CO}_{3}, 2.92 \mathrm{NaHCO}_{3}$, distilled water to $1000 \mathrm{ml}$. Adjust $\mathrm{pH}$ to 9.6 with $\mathrm{HCl}$.

2. 96-well microtiter plates (Nunc, Rochester, NY, USA).

3. Coating MAbs: BCoV MAbs (developed against HE, S and N proteins of BCoV) (50).

4. Phosphate buffered saline (PBS) $10 \mathrm{X}$ stock: $1.37 \mathrm{M} \mathrm{NaCl}, 27 \mathrm{mM} \mathrm{KCl}, 100 \mathrm{mM}$ $\mathrm{Na}_{2} \mathrm{HPO}_{4}, 18 \mathrm{mM} \mathrm{KH}_{2} \mathrm{PO}_{4}$ (adjust $\mathrm{pH}$ to 7.2 with $\mathrm{HCl}$ ).

5. Wash buffer: PBS pH 7.2 containing $0.05 \%$ Tween-20.

6. Blocking buffer: $5 \%(\mathrm{w} / \mathrm{v})$ nonfat dry milk (NFDM) in PBS.

7. Primary and secondary Abs-dilution buffer: PBS pH 7.2 containing $0.05 \%$ Tween-20.

8. Primary Ab: Guinea pig antiserum to BCoV Mebus strain.

9. Secondary Ab: Goat anti-guinea pig IgG horseradish peroxidase (HRP) conjugate (KPL, Gaithersburg, MD, USA).

10. TMB (3,3',5,5'-tetramethylbenzidine) microwell peroxidase substrate (KPL).

11. Stop solution: $1 \mathrm{M}$ phosphoric acid $\left(\mathrm{H}_{3} \mathrm{PO}_{4}\right)$.

\subsection{Antibody-Capture ELISA (Serological Test) for Detection of Virus-Specific Antibodies}

1. Coating buffer: 0.1 M carbonate bicarbonate buffer (as described in Section 2.2).

2. 96-well microtiter plates (Nunc).

3. Coating MAbs: BCoV MAbs (developed against $\mathrm{HE}, \mathrm{S}$ and $\mathrm{N}$ proteins of $\mathrm{BCoV})$. 
4. Phosphate buffered saline (PBS), as described in Section 2.2.

5. Wash buffer: PBS pH 7.2 containing $0.05 \%$ Tween-20.

6. Blocking buffer: $5 \%(\mathrm{w} / \mathrm{v})$ NFDM in PBS.

7. Dilution buffer: PBS pH 7.2 containing $0.05 \%$ Tween-20.

8. Goat anti-bovine IgG HRP conjugate (KPL).

9. TMB microwell peroxidase substrate (KPL).

10. Stop solution: $1 \mathrm{M}$ phosphoric acid $\left(\mathrm{H}_{3} \mathrm{PO}_{4}\right)$.

\subsection{RT-PCR Detection of Coronavirus RNA}

1. TRIzol LS reagent (Invitrogen, Carlsbad, CA, USA)

2. $0.2 \mathrm{ml}$ PCR tubes w/flat cap (Phenix, Hayward, CA, USA).

3. 10X thermophillic DNA polymerase buffer (Promega, Madison, WI, USA).

4. Magnesium chloride $25 \mathrm{mM}$ (Promega) (see Note 5).

5. $0.2 \mathrm{M}$ dNTPs mix (Promega).

6. Forward and reverse primers (see Table 2).

7. AMV Reverse Transcriptase (Promega).

8. RNasin (Promega).

9. Taq DNA polymerase (Promega).

10. Milli-Q diethylpyrocarbonate(DEPC)-treated water. Add DEPC (see Note 6) to Milli-Q water to a final concentration $0.1 \%$, incubate for $2 \mathrm{~h}$ at $37^{\circ} \mathrm{C}$ with occasional shaking and autoclave (to dissociate DEPC).

11. $6 \mathrm{X}$ blue/range loading dye (Promega).

12. Ethidium bromide solution with concentration of $0.5 \mu \mathrm{g} / \mathrm{ml}$.

13. Tris-acetate-EDTA (TAE) buffer: $2 \mathrm{M}$ Tris-base, $2 \mathrm{M}$ acetic acid, $0.05 \mathrm{M}$ EDTA ( $\mathrm{pH} 8.0)$.

14. Agarose I, biotechnology grade (Amresco, Solon, OH, USA).

\section{Methods}

\subsection{Virus Isolation and Plaque Induction}

\subsubsection{Preparation of Fecal and Nasal Samples}

Fecal and nasal samples are used for virus isolation, antigen capture ELISA, and RNA extraction for RT-PCR. Feces from animals (domestic cattle or wild ruminants), with or without clinical signs, should be collected in sterile fecal cups, put on ice, and transported. Then, $0.5 \mathrm{~g}$ of fecal sample is diluted in $4 \mathrm{ml}$ of Dil. \#5, vortexed, and centrifuged at $2000 \times g$ for $30 \mathrm{~min}$. The supernatant is aspirated and stored at $-70^{\circ} \mathrm{C}$ until use. Samples should be filtered (using 0.22 -nm filters) before inoculation onto the HRT-18 cell culture monolayers.

Paired sterile polyester-tipped swabs are used to collect nasal secretions from each nostril of domestic cattle or wild ruminants, put on ice and transported. 


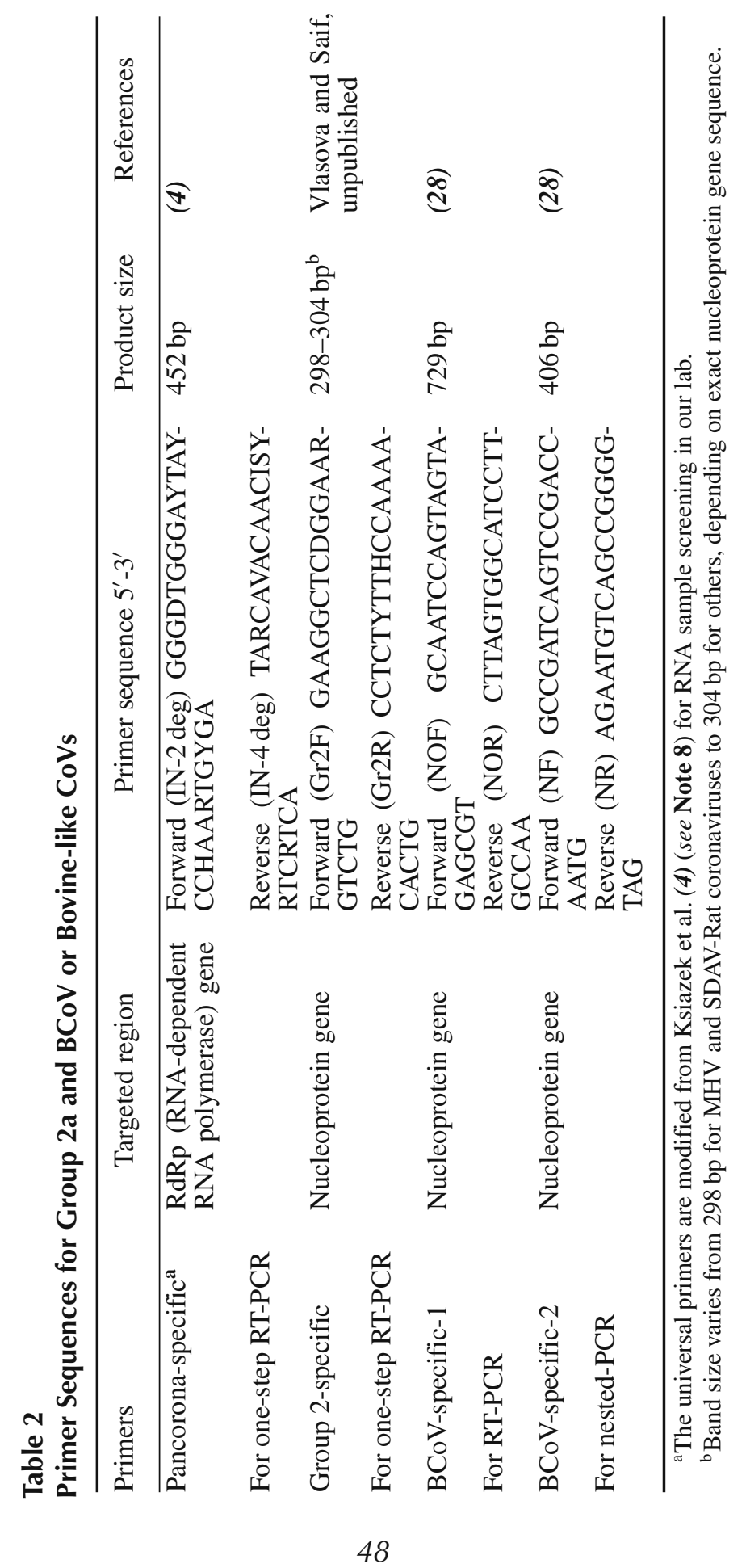


They are placed in $4 \mathrm{ml}$ of Dil. \#5, vortexed, and centrifuged at $2000 \times g$ for $30 \mathrm{~min}$. Then the supernatant is aspirated and stored at $-70^{\circ} \mathrm{C}$ until use. Samples should be filtered (using 0.22-nm filters) before inoculation onto the HRT-18 cell culture monolayers.

\subsubsection{Virus Isolation in HRT-18 Cell Cultures (48)}

1. Monolayers of HRT-18 cell cultures, 3 to 5 days after seeding $(44,48,49)$ into six-well plates are washed twice and incubated with Dil. \#5 (3 ml per well) for $3 \mathrm{~h}$ at $37^{\circ} \mathrm{C}$ in a $5 \% \mathrm{CO}_{2}$ atmosphere.

2. Dil. \#5 is aspirated from the wells and the cells are inoculated (in duplicate wells) with the fecal or nasal supernatants ( $200 \mu \mathrm{l}$ per well), which are BCoV-positive by ELISA or RT-PCR. The supernatants are adsorbed for $1 \mathrm{~h}$, during which time the plates are hand-rocked every $15 \mathrm{~min}$. Then $3 \mathrm{ml}$ of MEM containing pancreatin $(5 \mu \mathrm{g} / \mathrm{ml})$ is added to each well (see Note 2). The inoculated cells are incubated for 3 to 4 days at $37^{\circ} \mathrm{C}$ in a $5 \% \mathrm{CO}_{2}$ atmosphere. Cultures are examined daily for evidence of cytopathic effects (CPE).

3. The CPE, characterized by enlarged, rounded, and detached cells are usually observed approximately $72 \mathrm{~h}$ after inoculation, after five to seven initial blind passages (Fig. 1).

4. Immunofluorescence, Ag-ELISA, and RT-PCR tests can be used to confirm virus presence.

\subsubsection{Plaque Induction in HRT-18 Cell Cultures}

1. Monolayers of HRT- 18 cell cultures, 3 to 5 days after seeding into six-well plates are washed twice and incubated with Dil. \#5 (3 ml per well) for $3 \mathrm{~h}$ at $37^{\circ} \mathrm{C}$ in a $5 \% \mathrm{CO}_{2}$ atmosphere (48).

2. Dil. \#5 is aspirated from the wells and the cells are then inoculated (in duplicate wells) with CPE positive virus dilutions of $10^{-2}$ to $10^{-7}$ (200 $\mu$ l per well).
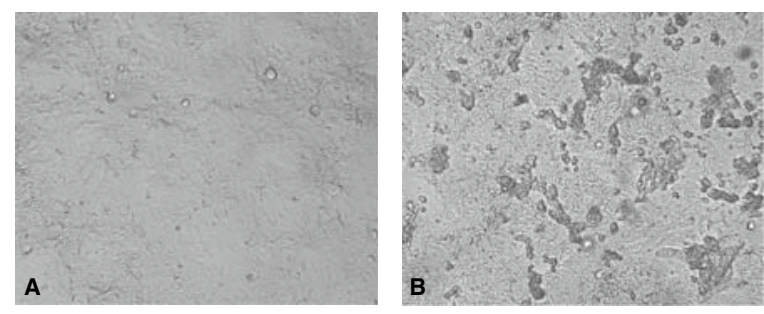

Fig. 1. (A) Mock-inoculated HRT-18 cell culture; (B) CPE in the HRT-18 cell culture inoculated $72 \mathrm{~h}$ previously with bovine-like coronavirus (isolated from giraffe feces). 
3. After virus adsorption, plates are overlaid with MEM containing $1.6 \%$ noble agar plus $0.1 \%$ neutral red, $0.1 \%$ pancreatin, and $1 \%$ diethylaminoethyl dextran. Plates are inverted and incubated at $37^{\circ} \mathrm{C}$ in a $5 \% \mathrm{CO}_{2}$ atmosphere for 3 to 5 days.

4. Usually plaques appear within 3-5 days and diameters are approximately 0.8 to $1.5 \mathrm{~mm}$.

\subsection{Antigen-Capture ELISA for Detection of Viral Antigens}

1. All wells of rows A, B, E, and F in 96-well flat bottom microtiter plates are coated with $100 \mu \mathrm{l}$ of pooled BCoV MAbs (MAbs produced as mouse ascites against $\mathrm{HE}, \mathrm{S}$, and $\mathrm{N}$ proteins of $\mathrm{BCoV}$ ) diluted in coating buffer as the capture antibody (50). All wells of $\mathrm{C}, \mathrm{D}, \mathrm{G}$, and $\mathrm{H}$ rows of plates are coated with $100 \mu \mathrm{l}$ of $\mathrm{BCoV}$ negative mouse ascites $(\mathrm{Sp} 2 / 0)$. Plates are incubated at $4{ }^{\circ} \mathrm{C}$ overnight and rinsed four times with wash buffer.

2. The wells are blocked with $5 \%$ NFDM (200 $\mu$ l per well) and incubated at room temperature for $2 \mathrm{~h}$. The blocking solution is aspirated and the wells are washed four times with wash buffer.

3. The prepared fecal or nasal samples and positive and negative control samples (see Note 3) are added to four appropriate wells (two wells with positive and two wells with negative coating for each sample) (100 $\mu$ l per well). For example: positive control sample to $1 \mathrm{~A}, 1 \mathrm{~B}, 1 \mathrm{C}$, and $1 \mathrm{D}$; negative control sample to $2 \mathrm{~A}, 2 \mathrm{~B}$, 2C, and 2D; sample \#1 to 3A, 3B, 3C, and 3D, etc. Plates are incubated at room temperature for $1 \mathrm{~h}$ in the dark and then washed four times with wash buffer.

4. Diluted guinea pig antiserum to $\operatorname{BCoV}(1: 200-1: 400)$ is added (100 $\mu$ l per well) as the primary antibody and the plates are incubated at room temperature for $1 \mathrm{~h}$ (for nasal samples antiserum should be used twice as concentrated as for fecal samples: 1:200). Then plates are washed four times with wash buffer.

5. Goat anti-guinea pig IgG HRP conjugate (KPL) diluted 1:8000 is added (100 $\mu 1$ per well). The plates are then incubated at room temperature for $1 \mathrm{~h}$ and washed four times with wash buffer.

6. Finally, TMB microwell peroxidase substrate (KPL) is added (100 $\mu$ l per well) and after $15 \mathrm{~min}$ incubation at room temperature, $1 \mathrm{M}$ phosphoric acid $\left(\mathrm{H}_{3} \mathrm{PO}_{4}\right)$ (50 $\mu \mathrm{l}$ per well) is applied as a stopping solution.

7. The cutoff value is calculated as the mean absorbance (450-nm wavelength) of the negative coating wells plus 3 standard deviations. Samples with an absorbance value higher than the cutoff value are considered positive.

\subsection{Antibody-Capture ELISA (Serological Test) for Detection of Virus-Specific Antibodies in Bovine or Wild-Ruminant Serum (51)}

1. Blood is collected and allowed to clot. Then serum is aspirated, heat inactivated $\left(56^{\circ} \mathrm{C}, 30 \mathrm{~min}\right)$, and stored at $-20^{\circ} \mathrm{C}$ until use. 
2. All wells of rows A, B, E, and F in a 96-well flat bottom microtiter plate are coated with $100 \mu \mathrm{l}$ of $\mathrm{BCoV}$ MAbs (developed against $\mathrm{HE}, \mathrm{S}$, and $\mathrm{N}$ proteins of $\mathrm{BCoV}$ ) diluted in coating buffer as the capture antibody $(\mathbf{5 0 , 5 1 )}$. All wells of $\mathrm{C}, \mathrm{D}, \mathrm{G}$, and $\mathrm{H}$ rows of the plate are coated with $100 \mu \mathrm{l}$ of $\mathrm{BCoV}$ negative ascites (Sp2/0). Plates are incubated at $4^{\circ} \mathrm{C}$ overnight and rinsed four times with wash buffer.

3. The wells are then blocked with 5\% NFDM (200 $\mu$ l per well) and incubated at room temperature for $2 \mathrm{~h}$. The blocking solution is discarded and the wells are washed four times with wash buffer.

4. Supernatants of HRT-18 cell cultures inoculated with BCoV Mebus strain are added to each well (100 $\mu$ l per well). Plates are incubated at room temperature for $2 \mathrm{~h}$ in the dark and then washed four times with wash buffer.

5. The serum samples and positive and negative control serum samples (see Note 1; Section 2.3.3) are added to four appropriate wells (two wells with positive and two wells with negative coating per sample) (100 $\mu \mathrm{l}$ per well); e.g.: positive control sample to $1 \mathrm{~A}, 1 \mathrm{~B}, 1 \mathrm{C}$, and $1 \mathrm{D}$; negative control sample to $2 \mathrm{~A}, 2 \mathrm{~B}, 2 \mathrm{C}$, and $2 \mathrm{D}$; sample \#1 to 3A, 3B, 3C, and 3D. Plates are incubated at $37^{\circ} \mathrm{C}$ for $1 \mathrm{~h}$.

6. The plates are rinsed four times with wash buffer and goat anti-bovine IgG peroxidase conjugate (KPL) (1:4000) is added (or peroxidase conjugated Protein A, if ruminant sera fail to react with anti-bovine $\mathrm{IgG}), 100 \mu \mathrm{l}$ per well. After incubation at $37^{\circ} \mathrm{C}$ for $1 \mathrm{~h}$ plates are washed four times with wash buffer.

7. Finally, TMB peroxidase substrate (KPL) is added (100 $\mu$ l per well) and after $15 \mathrm{~min}$ incubation at room temperature, $1 \mathrm{M}$ phosphoric acid $\left(\mathrm{H}_{3} \mathrm{PO}_{4}\right)(50 \mu \mathrm{l}$ per well) is applied as a stop solution.

8. The cutoff value is calculated as the mean absorbance (450-nm wavelength) from the negative coating wells plus 3 standard deviations. Samples with absorbance value higher than the cutoff value are considered positive.

\subsection{RT-PCR Detection of Coronavirus RNA (ref. 28 and Vlasova and Saif, Unpublished)}

\subsubsection{RNA Extraction}

TRIzol LS reagent is used for viral RNA extraction from fecal and nasal samples following the manufacturer's protocol (see Note 7). Briefly:

1. A $250-\mu l$ sample is mixed with $750 \mu \mathrm{l}$ TRIzol LS in an Eppendorf tube, vortexed, and incubated for $5 \mathrm{~min}$ at room temperature.

2. Then $200 \mu \mathrm{l}$ chloroform is added to each tube, vortexed for a short time, and incubated for $10 \mathrm{~min}$ at room temperature.

3. After centrifugation, at $12,000 \times g$ for $15 \mathrm{~min}$ at $4^{\circ} \mathrm{C}$, the supernatant $(400 \mu \mathrm{l})$ is transferred to new Eppendorf tubes and an equal volume of 100\% isopropyl alcohol is added to each tube. Tubes are vortexed and incubated for $10 \mathrm{~min}$ at room temperature. 
4. Then tubes are centrifuged at $12,000 \times g$ for $10 \mathrm{~min}$ at $4^{\circ} \mathrm{C}$, the supernatant is discarded, and $800 \mu \mathrm{l}$ of $75 \% \mathrm{EtOH}$ is added to each tube.

5. Samples are vortexed and centrifuged at $7500 \times g$ for 5 min at $4{ }^{\circ} \mathrm{C}$.

6. Finally, the supernatants are removed gently, the pellet is dried using a DNA Speed Vac dry machine (model DNA110, Savant INC, NY) low spin for $10 \mathrm{~min}$ and $40 \mu \mathrm{l}$ RNase-free (DEPC-treated) water is added for elution.

7. After incubation at $55^{\circ}-60^{\circ} \mathrm{C}$ for $10 \mathrm{~min}$, RNA samples should be stored at $-20^{\circ} \mathrm{C}$ or applied directly for one-step or nested RT-PCR.

\subsubsection{One-Step RT-PCR}

1. Each primer pair listed in Table 2 can be used for detection of the BCoV or bovinelike (wild-ruminant) $\mathrm{CoV}$ genomes. A pancorona-specific primer pair modified from Ksiazek et al. (4), targeted to the conserved region of the RNA-dependent RNA polymerase ( $\mathrm{RdRp}$ ), is capable of universal detection of known coronaviruses (see Note 8). Group 2a-specific primers were designed based on the consensus sequence of the nucleoprotein gene for group 2 a coronaviruses (see Note 9). The $\mathrm{BCoV}$-specific primers are targeted to the nucleoprotein and can also amplify a specific fragment for $\mathrm{BCoV}$ and the related wild-ruminant CoVs, but not other group 2 coronaviruses (28).

2. Reaction conditions are optimized using RT-PCR reagents commercially available from Promega, but they are easily adapted to enable the use of alternative reagents.

3. The typical PCR master mix should contain the following reagents in the 0.2-ml PCR tubes (RNAse/DNAse and Pyrogene safe): 10X thermophillic DNA polymerase buffer $(2.5 \mu \mathrm{l})$; magnesium chloride $2.5 \mathrm{mM}$; 0.2 M dNTPs mix; forward and reverse primers 50 pmol each; AMV reverse transcriptase $2.5 \mathrm{U}$; RNasin $10 \mathrm{U}$; Taq DNA polymerase 1.25 U; adjust volume with Milli-Q DEPC-treated water to $23 \mu 1.2-\mu 1$ RNAs extracted from the samples is added to each tube. RNA extracted from mock-inoculated HRT-18 cell culture supernatants or negative fecal or nasal samples and water should be used as negative controls and BCoV-infected HRT18 cell culture supernatants or BCoV-positive fecal or nasal samples as positive controls.

4. The following RT-PCR cycles should be used: $42^{\circ} \mathrm{C}$ for $60 \mathrm{~min}, 94^{\circ} \mathrm{C}$ for $5 \mathrm{~min}$; 35 cycles at $94^{\circ} \mathrm{C}$ for $0.5 \mathrm{~min}, 50^{\circ} \mathrm{C} / 56^{\circ} \mathrm{C}$ (see Note 10) for $0.5 \mathrm{~min}, 72^{\circ} \mathrm{C}$ for $1 \mathrm{~min}, 72^{\circ} \mathrm{C}$ for $7 \mathrm{~min}$, and hold at $4^{\circ} \mathrm{C}$.

\subsubsection{Nested PCR (28)}

The nested-PCR protocol is as described for the RT-PCR procedure above (Section 3.4.2), but with minor modifications. For the nested-PCR master mix, $5 \mu$ l of undiluted RT-PCR product (cDNA) is used as a template instead of the RNA sample. The PCR master mix should not contain AMV reverse transcriptase and RNasin. For precautions against cross-contamination (see Note 11). 


\subsubsection{Electrophoresis}

1. $10 \mu \mathrm{l}$ of PCR product is mixed with $2 \mu \mathrm{l}$ of $6 \mathrm{X}$ Blue/Orange loading dye (Promega).

2. Load premixed samples in a $2 \%$ agarose gel in $1 \mathrm{X}$ TAE buffer containing ethidium bromide at a final concentration of $0.5 \mu \mathrm{g} / \mathrm{ml}$. Add DNA molecular weight ladder also premixed with loading buffer.

3. Run the gel at $125 \mathrm{~V}$ for $25 \mathrm{~min}$.

4. Visualize results using UV transilluminator (312-nm wavelength).

\section{Conclusions}

In summary, multiple diagnostic tests have been developed and standardized for the routine diagnosis of $\mathrm{BCoV}$ and the closely related ruminant Group 2a CoVs. These include antigen or antibody detection by ELISA, virus isolation in cell culture (HRT-18 cells), and, often the most sensitive method, detection of viral RNA by RT-PCR. These methods have provided evidence for the presence of $\mathrm{CoVs}$ closely related genetically or antigenically to $\mathrm{BCoV}$, not only from wild ruminants, but also from dogs (21) and humans (53). These findings and experimental transmission studies $(\mathbf{8 , 4 4 , 5 4 )}$ confirm a broad host range for bovine-like group 2a CoVs and support a need to monitor their presence in other host species, including humans, by applying the diagnostic assays outlined in this chapter and the sequencing of new isolates.

\section{Notes}

1. FBS used for the cell cultures should be inactivated by heating at $56^{\circ} \mathrm{C}$ for $30 \mathrm{~min}$ and should be validated as bovine viral diarrhea virus-free.

2. After absorption of samples ( $1 \mathrm{~h}$ ), washing the cells with Dil. \#5 can help to avoid cytotoxic effects.

3. The positive control sample is from supernatant of HRT-18 cell cultures inoculated with $\mathrm{BCoV}$ Mebus strain and the negative control sample is from supernatants of mock-inoculated HRT-18 cell cultures. Alternatively, diluted feces from a $\mathrm{BCoV}$ - or mock-inoculated gnotobiotic calf can be used as positive and negative controls, respectively $(28,37,44)$.

4. Positive control serum sample is hyperimmune serum from a gnotobiotic calf inoculated with BCoV-440 and negative control serum sample is serum from a mock-inoculated gnotobiotic calf $(28,37,44)$.

5. All solutions should be prepared in water that has a resistivity of $18 \mathrm{M} \Omega-\mathrm{cm}$, unless stated otherwise.

6. Diethyl pyrocarbonate (DEPC) is a carcinogen, so a fume hood should be used when working with this reagent.

7. Some fecal samples from conventional animals can contain PCR inhibitors, especially if they were frozen. If such a problem occurs, dilution of extracted 
RNA (1:10-1:20) can be helpful; if inhibitors persist, commercial kits (Epicentre, QIAGEN) optimized for DNA extraction from fecal samples should be used.

8. The conserved region of the RdRp was initially chosen as a target to allow universal detection of all CoVs. The original universal primer pair targeted to this region from Ksiazek et al. (4) was not optimal in RT-PCR with some CoV samples from wild ruminants. Thus, based on the consensus sequence (for all available RdRp sequences of coronaviruses from different groups) in all polymorphic positions, degenerative nucleotides were introduced. After these primers were tested with positive samples (validated in other assays), they demonstrated consistently positive results.

9. The coronavirus nucleoprotein gene was chosen for group-specific primer development because it has been shown to be variable in amino acid and nucleotide composition among the viruses that comprise the three coronavirus antigenic groups, but highly conserved within these groups.

10 The optimal melting temperature for group 2a- specific primers and nested-PCR is $56^{\circ} \mathrm{C}$; for pancorona- and $\mathrm{BCoV}$-specific primers, the optimal melting temperature is $50^{\circ} \mathrm{C}$.

11. If RT-PCR sensitivity is low, a nested PCR method can increase PCR product yield. However, this will also increase the risk of cross-contamination. Standard precautions to avoid cross-contamination should be implemented. These include: use of gloves with frequent changing; employing of aerosol resistant pipettors and pipette tips; preparing of PCR master mixes in UV cabinets that should never be used for work with any sample materials or PCR DNA products; regular decontamination of work surfaces and all equipment with $10 \%$ chlorine or another commercially available disinfectant; separate working areas for each step of the PCR analysis as well as separate storage areas for PCR reagents and contaminated samples (47).

\section{References}

1. Birch, C. J., Clothier, H. J., Seccull, A., Tran, T., Catton, M. C., Lambert, S. B., and Druce, J. D. (2005) Human coronavirus OC43 causes influenza-like illness in residents and staff of aged-care facilities in Melbourne, Australia. Epidemiol. Infect. 133, 273-277.

2. Saif, L. J., and Heckert, R. A. (1990) Enteropathogenic coronaviruses. In: Saif, L. J., and Theil, K. W. (ed.) Viral Diarrheas of Man and Animals. CRC Press, Boca Raton, FL, pp. 185-252.

3. Woo, P. C. Y., Lau, S. K. P., Chu, C.-M., Chan, K.-H., Tsoi, H.-W., Huang, Y., Wong, B. H. L., Poon, R. W. S., Cai, J. J., Luk, W.-K., Poon, L. L. M., Wong S. S. Y., Guan, Y., Peiris, J. S. M., and Yuen, K.-Y. (2005) Characterization and complete genome sequence of a novel coronavirus, coronavirus HKU1, from patients with pneumonia. J. Virol. 79, 884-895. 
4. Ksiazek, T. G., Erdman, D., Goldsmith, C. S., Zaki, S. R., Peret, T., Emery, S., Tong, S., Urbani, C., Comer, J. A., Lim, W., Rollin, P. E., Dowell, S. F., Ling, A. E., Humphrey, C. D., Shieh, W. J., Guarner, J., Paddock, C. D., Rota, P., Fields, B., DeRisi, J., Yang, J. Y., Cox, N., Hughes, J. M., LeDuc, J. W., Bellini, W. J., Anderson, L. J., and Group, S. W. (2003) A novel coronavirus associated with severe acute respiratory syndrome. N. Eng. J. Med. 348, 1953-1966.

5. Kuiken, T., Fouchier, R. A., Schutten, M., Rimmelzwaan, G. F., van Amerongen, G., van Riel, D., Laman, J. D., de Jong, T., van Doornum, G., Lim, W., Ling, A. E., Chan, P. K., Tam, J. S., Zambon, M. C., Gopal, R., Drosten, C., van der Werf, S., Escriou, N., Manuguerra, J. C., Stohr, K., Peiris, J. S., and Osterhaus, A. D. (2003) Newly discovered coronavirus as the primary cause of severe acute respiratory syndrome. Lancet 362, 263-270.

6. Li, W., Wong, S. K., Li, F., Kuhn, J. H., Huang, I. C., Choe, H., and Farzan, M. (2006) Animal origins of the severe acute respiratory syndrome coronavirus: insight from ACE2-S-protein interactions. J. Virol. 80, 4211-4219.

7. Peiris, J. S., Guan, Y., and Yuen, K. Y. (2004) Severe acute respiratory syndrome. Nature Med. 10, S88-S97.

8. Saif, L. J. (2005) Comparative biology of animal coronaviruses: lessons for SARS. In: Peiris, M., Anderson, L. J., Osterhous, A. D. M. E., Stohr, K., and Yuen, K.Y. (ed.)Severe Acute Respiratory Syndrome. Blackwell, Malden, MA, pp. 84-99.

9. Saif, L. J. (2004) Animal coronaviruses: Lessons for SARS. In: Knobler, S., Mahmous, A., Lemon, S., Mack, A., Sivitz, L. and Oberholtzer, K. (ed.) Learning from SARS: Preparing for the Next Disease Outbreak. The National Academies Press, Washington, DC, pp. 138-149.

10. Wang, M., Yan, M., Xu, H., Liang, W., Kan, B., Zheng, B., Chen, H., Zheng, H., Xu, Y., Zhang, E., Wang, H., Ye, J., Li, G., Li, M., Cui, Z., Liu, Y. F., Guo, R. T., Liu, X. N., Zhan, L. H., Zhou, D. H., Zhao, A., Hai, R., Yu, D., Guan, Y. and $\mathrm{Xu}, \mathrm{J}$. (2005) SARS-CoV infection in a restaurant from palm civet. Emerg. Infect. Diseases 11, 1860-1865.

11. Guan, Y., Zheng, B. J., He, Y. Q., Liu, X. L., Zhuang, Z. X., Cheung, C. L., Luo, S. W., Li, P. H., Zhang, L. J., Guan, Y. J., Butt, K. M., Wong, K. L., Chan, K. W., Lim, W., Shortridge, K. F., Yuen, K. Y., Peiris, J. S., and Poon, L. L. (2003) Isolation and characterization of viruses related to the SARS coronavirus from animals in southern China. Science 302, 276-278.

12. Lau, S. K., Woo, P. C., Li, K. S., Huang, Y., Tsoi, H. W., Wong, B. H., Wong, S. S., Leung, S. Y., Chan, K. H., and Yuen, K. Y. (2005) Severe acute respiratory syndrome coronavirus-like virus in Chinese horseshoe bats. Proc. Natl. Acad. Sci. USA 102, 14040-14045.

13. Li, W., Shi, Z., Yu, M., Ren, W., Smith, C., Epstein, J. H., Wang, H., Crameri, G., Hu, Z., Zhang, H., Zhang, J., McEachern, J., Field, H., Daszak, P., Eaton, B. T., Zhang, S., and Wang, L. F. (2005) Bats are natural reservoirs of SARS-like coronaviruses. Science 310, 676-679.

14. Haring, J., and Perlman, S. (2001) Mouse hepatitis virus. Curr. Opin. Microbiol. 4, $462-466$. 
15. Matthews, A. E., Weiss, S. R., and Paterson, Y. (2002) Murine hepatitis virus-a model for virus-induced CNS demyelination. J. Neurovirol. 8, 76-85.

16. Yount, B., Denison, M. R., Weiss, S. R. and Baric, R. S. (2002) Systematic assembly of a full-length infectious cDNA of mouse hepatitis virus strain A59. J. Virol. 76, 11065-11078.

17. Vijgen, L., Keyaerts, E., Moes, E., Thoelen, I., Wollants, E., Lemey, P., Vandamme, A. M. and Ranst M. V. (2005) Complete genomic sequence of human coronavirus OC43: molecular clock analysis suggests a relatively recent zoonotic coronavirus transmission event. J. Virol. 79, 1595-1604.

18. Vabret, A., D. J., Gouarin, S., Petitjean, J., Corbet, S., and Freymuth F. (2006) Detection of the new human coronavirus HKUI: a report of 6 cases. Clin. Infect. Dis. 42, 634-639.

19. Pensaert, M. B., and Andries, K. (1986) Hemagglutinating encephalomyelitis virus. In: Leman, A. D., Straw, B. E., Glock, R. D., Mengeling, W. L., Penny, R. H., Scholl, E. (ed.) Diseases of Swine. Iowa State University Press, Ames, pp. 310-315.

20. Erles, K., and Brownlie, J. (2005) Investigation into the causes of canine infectious respiratory disease: antibody responses to canine respiratory coronavirus and canine herpesvirus in two kennelled dog populations. Arch. Virol. 150, 1493-1504.

21. Erles, K., Toomey, C., Brooks, H. W., and Brownlie, J. (2003) Detection of a group 2 coronavirus in dogs with canine infectious respiratory disease. Virology 310, 216-223.

22. Guy, J. S., Breslin, J. J., Breuhaus, B., Vivrette, S., and Smith, L. G. (2000) Characterization of a coronavirus isolated from a diarrheic foal. J. Clin. Microbiol. 38, 4523-4526.

23. Barker, M. G., Percy, D. H., Hovland, D. J., and MacInnes, J. I. (1994) Preliminary characterization of the structural proteins of the coronaviruses, sialodacryoadenitis virus and Parker's rat coronavirus. Can. J. Vet. Res. 58, 99-103.

24. Homberger, F. R., Smith, A. L., and Barthold, S. W. (1991) Detection of rodent coronaviruses in tissues and cell cultures by using polymerase chain reaction. $J$. Clin. Microbiol. 29, 2789-2793.

25. Percy, D., Bond, S., and MacInnes, J. (1989) Replication of sialodacryoadenitis virus in mouse L-2 cells. Arch. Virol. 104, 323-333.

26. Smith, A. L. (1983) An immunofluorescence test for detection of serum antibody to rodent coronaviruses. Lab. Anim. Sci. 33, 157-160.

27. Cho, K. O., Halbur, P. G., Bruna, J. D., Sorden, S. D., Yoon, K. J., Janke, B. H., Chang, K. O., and Saif, L. J. (2000) Detection and isolation of coronavirus from feces of three herds of feedlot cattle during outbreaks of winter dysentery-like disease. J. Am. Vet. Med. Assoc. 217, 1191-1194.

28. Cho, K. O., Hasoksuz, M., Nielsen, P. R., Chang, K. O., Lathrop, S., and Saif, L. J. (2001) Cross-protection studies between respiratory and calf diarrhea and winter dysentery coronavirus strains in calves and RT-PCR and nested PCR for their detection. Arch. Virol. 146, 2401-2419. 
29. Hasoksuz, M., Hoet, A. E., Loerch, S. C., Wittum, T. E., Nielsen, P. R., and Saif, L. J. (2002) Detection of respiratory and enteric shedding of bovine coronaviruses in cattle in an Ohio feedlot. J. Vet. Diagn. Invest. 14, 308-313.

30. Heckert, R. A., Saif, L. J., Hoblet, K. H., and Agnes, A. G. (1990) A longitudinal study of bovine coronavirus enteric and respiratory infections in dairy calves in two herds in Ohio. Vet. Microbiol. 22, 187-201.

31. Mebus, C. A., Stair, E. L., Rhodes, M. B., and Twiehaus, M. J. (1973) Neonatal calf diarrhea: propagation, attenuation, and characteristics of a coronavirus-like agent. Am. J. Vet. Res. 34, 145-150.

32. Saif, L. J. (1990) A review of evidence implicating bovine coronavirus in the etiology of winter dysentery in cows: an enigma resolved? Cornell Vet. 80, 303-311.

33. Traven, M., Naslund, K., Linde, N., Linde, B., Silvan, A., Fossum, C., Hedlund, K. O. and Larsson, B. (2001) Experimental reproduction of winter dysentery in lactating cows using $\mathrm{BCV}$ - comparison with BCV infection in milk-fed calves. Vet. Microbiol. 81, 127-151.

34. Tsunemitsu, H., Smith, D. R., and Saif, L. J. (1999) Experimental inoculation of adult dairy cows with bovine coronavirus and detection of coronavirus in feces by RT-PCR. Arch. Virol. 144, 167-175.

35. Smith, D. R., Fedorka-Cray, P. J., Mohan, R., Brock, K. V., Wittum, T. E., Morley, P. S., Hoblet, K. H., and Saif, L. J. (1998) Epidemiologic herd-level assessment of causative agents and risk factors for winter dysentery in dairy cattle. Am. J. Vet. Res. 59, 994-1001.

36. Thomas, L. H., Gourlay, R. N., Stott, E. J., Howard, C. J. and Bridger, J. C. (1982) A search for new microorganisms in calf pneumonia by the inoculation of gnotobiotic calves. Res. Vet. Sci. 33, 170-182.

37. Hasoksuz, M., Lathrop, S. L., Gadfield, K. L., and Saif, L. J. (1999) Isolation of bovine respiratory coronaviruses from feedlot cattle and comparison of their biological and antigenic properties with bovine enteric coronaviruses. Am. J. Vet. Res. 60, 1227-1233.

38. Lathrop, S. L., Wittum, T. E., Brock, K. V., Loerch, S. C., Perino, L. J., Bingham, H. R., McCollum, F. T., and Saif, L. J. (2000) Association between infection of the respiratory tract attributable to bovine coronavirus and health and growth performance of cattle in feedlots. Am. J. Vet. Res. 61, 1062-1066.

39. Storz, J., Stine, L., Liem, A., and Anderson G. A. (1996) Coronavirus isolation from nasal swab sample in cattle with signs of respiratory tract disease after shipping. J. Am. Vet. Med. Assoc. 208, 1452-1455.

40. Lin, X. Q., O'Reilly, K. L., and Storz, J. (2002) Antibody responses of cattle with respiratory coronavirus infections during pathogenesis of shipping fever pneumonia are lower with antigens of enteric strains than with those of a respiratory strain. Clin. Diagn. Lab. Immunol. 9, 1010-1013.

41. Hasoksuz, M., Lathrop, S., Al-dubaib, M. A., Lewis, P., and Saif, L. J. (1999) Antigenic variation among bovine enteric coronaviruses (BECV) and bovine respiratory coronaviruses (BRCV) detected using monoclonal antibodies. Arch. Virol. 144, 2441-2447. 
42. Hasoksuz, M., Sreevatsan, S., Cho, K. O., Hoet, A. E., and Saif, L. J. (2002) Molecular analysis of the $\mathrm{S} 1$ subunit of the spike glycoprotein of respiratory and enteric bovine coronavirus isolates. Virus Res. 84, 101-109.

43. Tsunemitsu, H., and Saif, L. J. (1995) Antigenic and biological comparisons of bovine coronaviruses derived from neonatal calf diarrhea and winter dysentery of adult cattle. Arch. Virol. 140, 1303-1311.

44. Tsunemitsu, H., El-Kanawati, Z. R., Smith, D. R., Reed H. H. and Saif, L. J. (1995) Isolation of coronaviruses antigenically indistinguishable from bovine coronavirus from wild ruminants with diarrhea. J. Clin. Microbiol. 33, 3264-3269.

45. Majhdi, F., Minocha, H. C., and Kapil, S. (1997) Isolation and characterization of a coronavirus from Elk calves with diarrhea. J. Clin. Microbiol. 35, 2937-2942.

45a. Hasoksuz, M., Alekseev, K., Vlasova, A., Zhang, X., Spiro, D., Halpin, R., Wang, S., Ghedin, E., and Saif, L. J. (2007) Biologic, antigenic, and full-length genomic characterization of a bovine-like coronavirus isolated from a giraffe. $J$. Virol. 81(10), 4981-4990.

46. Chasey, D., Reynolds, D. J., Bridger, J. C., Debney, T. G., and Scott, A. C. (1984) Identification of coronaviruses in exotic species of Bovidae. Vet. Rec. 115, 602-603.

47. Elazhary, M. A., Frechette, J. L., Silim, A., and Roy, R. S. (1981) Serological evidence of some bovine viruses in the caribou (Rangifer tarandus caribou) in Quebec. J. Wildl. Dis. 17, 609-612.

48. Saif, L. J., Heckert, R. A., Miller, K. L., and Tarek, M. M. (1988) Cell culture propagation of bovine coronaviruses. J. Tiss. Cul. Meth. 11, 139-145.

49. Benfield, D. A., and Saif, L. J. (1990) Cell culture propagation of a coronavirus isolated from cows with winter dysentery. J. Clin. Microbiol. 28, 1454-1457.

50. Smith, D. R., Tsunemitsu, H., Keckert, R. A., and Saif, L. J. (1996) Evaluation of two antigen-capture ELISAs using polyclonal or monoclonal antibodies for the detection of bovine coronavirus. J. Vet. Diagn. Invest. 8, 99-105.

51. Smith, D. R., Nielsen, P. R., Gadfield, K. L., and Saif, L. J. (1998) Further validation of antibody-capture and antigen-capture enzyme-linked immunosorbent assays for determining exposure of cattle to bovine coronavirus. Am. J. Vet. Res. 59, 956-960.

52. Heckert, R. A., Saif, L. J., and Myers, G. W. (1989) Development of protein Agold immunoelectron microscopy for detection of bovine coronavirus in calves: comparison with ELISA and direct immunofluorescence of nasal epithelial cells. Vet. Microbiol. 19, 217-231.

53. Zhang, X. M., Herbst, W., Kousoulas, K. G., and Storz, J. (1994) Biological and genetic characterization of a hemagglutinating coronavirus isolated from a diarrhoeic child. J. Med. Virol. 44, 152-161.

54. Ismail, M. M., Cho, K. O., Hasoksuz, M., Saif, L. J., and Saif, Y. M. (2001) Antigenic and genomic relatedness of turkey-origin coronaviruses, bovine coronaviruses, and infectious bronchitis virus of chickens. Avian Dis. 45, 978-984. 
55. Vijgen, L., Keyaerts, E., Moes, E., Mais, P., Duson, G., and Van Ranst, M. (2005) Development of one-step, real-time, quantitative reverse transcriptase PCR assays for absolute quantitation of human coronaviruses OC43 and 229E. J. Clin. Microbiol. 43, 5452-5456.

56. Peters, R. L., Collins, M. J., O’Beirne, A. J., Howton, P. A., Hourihan, S. L., and Thomas, S. F. (1979) Enzyme-linked immunosorbent assay for detection of antibodies to murine hepatitis virus. J. Clin. Microbiol. 10, 595-597. 